\title{
The impact of smoking on HPV infection and the development of anogenital warts
}

\author{
Reto Kaderli • Beat Schnüriger • Lukas E. Brügger
}

Accepted: 8 June 2014 / Published online: 17 June 2014

(C) Springer-Verlag Berlin Heidelberg 2014

\begin{abstract}
Purpose The worldwide prevalence of human papillomavirus (HPV) infection is estimated at 9-13\%. Persistent infection can lead to the development of malignant and nonmalignant diseases. Low-risk HPV types are mostly associated with benign lesions such as anogenital warts. In the present systematic review, we examined the impact of smoking on HPV infection and the development of anogenital warts, respectively.

Methods A systematic literature search was performed using MEDLINE database for peer-reviewed articles published from January 01, 1985 to November 30, 2013. Pooled rates of HPV prevalence were compared using the $\chi^{2}$ test.

Results In both genders, smoking is associated with higher incidence and prevalence rates for HPV infection, whereas the latter responds to a dose-effect relationship. The overall HPV prevalence for smoking patients was 48.2 versus $37.5 \%$ for nonsmoking patients $(p<0.001)$ (odds ratio $(\mathrm{OR})=1.5,95 \%$ confidence interval (CI) 1.4-1.7). Smoking does also increase persistence rates for high-risk HPV infection, while this correlation is debatable for low-risk HPV. The incidence and recurrence rates of anogenital warts are significantly increased in smokers.

Conclusions Most current data demonstrate an association between smoking, increased anogenital HPV infection, and development of anogenital warts. These data add to the long
\end{abstract}

\footnotetext{
R. Kaderli $\cdot$ B. Schnüriger $(\bowtie) \cdot$ L. E. Brügger

Department of Visceral Surgery and Medicine, Bern University

Hospital, University of Bern, 3010 Bern, Switzerland

e-mail: beat.schnuriger@gmail.com

R. Kaderli

e-mail: reto.kaderli@insel.ch

L. E. Brügger

e-mail: lukas.bruegger@insel.ch
}

list of reasons for making smoking cessation a keystone of patient health.

Keywords Smoking $\cdot$ Human papillomavirus $\cdot$ Anogenital warts

\section{Introduction}

According to the World Health Organization (WHO), 630 million people are infected with genital human papillomavirus (HPV), resulting in an estimated worldwide prevalence of 9$13 \%[1,2]$. HPV is transmitted via genital contact and is the most common sexually transmitted infection worldwide [3, 4]. There is no consensus on a gender-specific risk of acquiring HPV [5]. Whereas at least $40 \%$ of HPV infections are asymptomatic and transient, with subsequent clearance by the immune system, some infections persist [2, 5]. Persistent infection can lead to the development of malignant and premalignant or nonmalignant diseases, so-called "anal intraepithelial neoplasia" (AIN). Over 100 HPV types have been identified. Approximately 40 of these affect the anogenital region $[2,6]$. HPV infections are detected by collecting material with brushes or swabs, followed by polymerase chain reaction analysis, genotyping, and HPV classification according to their risk of causing cervical cancer [2]: Low-risk HPV types are mostly associated with benign lesions such as anogenital warts (AIN grade I), and high-risk or oncogenic types are also associated with cancers and their precursors (AIN grade II/III) [6]. More than $90 \%$ of anogenital warts are caused by low-risk HPV types 6 and 11 [7,8]. Infected basal cells move toward the surface layer, where they ultimately develop to anogenital warts [2]. The worldwide prevalence of visible anogenital warts ranges from 0.13 to $5.1 \%$ [9]. These may regress spontaneously, with reported 
clearance rates varying widely from 0 to $55 \%$ [10-12]. However, even with therapy (topical, surgical, and/or destructive), the recurrence rate within 3 months is 25-67\% [10].

Apart from genital contact, risk factors for HPVacquisition include younger age, early coitarche, number of lifetime sexual partners, failure to use condoms consistently, marital status, history of sexually transmitted infections, immunosuppression (including patients with human immunodeficiency virus), history of other HPV-mediated neoplasia, and low socioeconomic status [13, 4]. Furthermore, smoking is postulated to be an additional risk factor, due to increased susceptibility to the acquisition of HPV [14].

In the present systematic review, we examined the impact of smoking on the incidence, persistence, and prevalence of HPV and of anogenital warts.

\section{Methods}

A systematic literature search was performed using MEDLINE database for peer-reviewed articles published in English. The search was carried out for articles published from January 01, 1985 to November 30, 2013, using the following keywords: smoking AND human papillomavirus AND/OR incidence AND/OR prevalence AND/OR persistence AND/OR condylomata acuminata AND/OR anogenital warts AND/OR genital warts. The references in the identified articles were also reviewed. Titles and abstracts, when available, were scrutinized to select relevant studies addressing the relation of smoking and HPV infection and/or the occurrence of anogenital warts. All studies addressing the relation in the abstract and/or the full text manuscript were subsequently included. Case reports, letters to editors, and review articles were excluded. In addition, studies restricted to patients with cervical or AIN and cervical or anal cancer were excluded. Furthermore, studies examining HPV infection or warts in other regions than the genital or anal were excluded.

Pooled rates of HPV prevalence were compared between smoking and nonsmoking patients, using the $\chi^{2}$ test. For this analysis, only prospective studies were included. As time intervals for incidence and persistence were different between studies with an analysis of different HPV types, comparison of these pooled rates was not practicable. To assess the clinical significance of differences in prevalence rates between smoking and nonsmoking patients, the $95 \%$ confidence interval (CI) for the difference was derived. Statistical Package for Social Sciences (SPSS Windows) version 21.0 (SPSS, Chicago, IL) was used for all analyses.

\section{Results}

\section{Incidence of HPV}

Fifteen studies (14 prospective and one retrospective) are available on the impact of smoking on the incidence of HPV [15-29]. The retrospective study-including 1,880 patientsdid not reveal an association [17]. Of the 14 prospective studies, 12 investigated genital [15, 16, 18-26, 29], one anogenital [27], and one solely anal [28] HPV infections. Nine of these 14 studies demonstrated a significant $[15,16,18,19$, $21,22,24,26,27]$, one a nonsignificant [20], and four no association between HPV incidence and smoking (Table 1) $[28,30,25,29]$.

A gender-specific analysis revealed that three out of four prospective studies including a total of 5,376 male patients found a significant association between smoking and the incidence of HPV [16, 27, 21]. Only one prospective study with 374 male patients did not reveal an association [23]. Similarly, six out of ten prospective studies comparing 27,508 smoking and nonsmoking female patients found a significant association [15, 18, 19, 22, 24, 26]. Additionally, Oh et al. found a statistically nonsignificant trend toward an association among female patients [20]. Three remaining prospective studies, including 1,339 female patients, did not reveal an association $[28,25,29]$.

Whereas the above-mentioned studies focused on the association of HPV incidence to current smoking, Partridge et al. found an association solely between past smoking and HPV infection (hazard ratio (HR) $=1.6,95 \%$ CI 1.1-2.4) [21].

\section{Persistence of HPV}

Thirteen prospective studies including a total of 18,529 patients investigated the impact of smoking on the persistence rate of anogenital HPV during time intervals of 4 [31], 6 [27, $32-34,23,35,16]$, or more $[36,37,20,38]$ months (one missing specification of time interval [39]). Nevertheless, the association between smoking and the persistence of HPV is not conclusive with regard to the number of patients in the two groups: Eleven of these 13 studies, including a total of 10,503 patients, found a statistically significant association (seven studies [27, 32, 33, 36, 31, 39, 38]) between HPV persistence and smoking or a trend (four studies [16, 20, 34, 23]) toward higher rates among smokers compared to nonsmokers [16, 27, 32, 33, 36, 31, 20, 34, 23, 39, 38]. Maucort-Boulch et al. even found a dose-effect relationship: Smoking $>20$ cigarettes per day was associated with a significantly increased risk of persistence of HPV infection among women, when compared with women who smoked $<10$ cigarettes per day (odds ratio $(\mathrm{OR})=1.43,95 \%$ CI 1.02-2.01) [33]. The remaining two studies prospectively included a total of 8,026 patients but could not establish a positive relationship between smoking 
Table 1 Summary of all prospective studies evaluating the association between the incidence of HPVand smoking

\begin{tabular}{|c|c|c|c|c|c|c|c|c|c|}
\hline Author & $\begin{array}{l}\text { Publication } \\
\text { year }\end{array}$ & $\begin{array}{l}\text { Study } \\
\text { design }\end{array}$ & $\begin{array}{l}\text { Population } \\
\text { (sex, } \\
\text { number of } \\
\text { patients } \\
\text { included) }\end{array}$ & Localization & $\begin{array}{l}\text { Association } \\
\text { with } \\
\text { smoking }\end{array}$ & $\begin{array}{l}\text { HPV } \\
\text { incidence in } \\
\text { nonsmoking } \\
\text { subjects }\end{array}$ & $\begin{array}{l}\text { HPV } \\
\text { incidence in } \\
\text { currently } \\
\text { smoking } \\
\text { subjects }\end{array}$ & $\begin{array}{l}\text { OR or HR } \\
\text { for } \\
\text { currently } \\
\text { smoking } \\
\text { subjects }\end{array}$ & $\begin{array}{l}\text { Specification of the } \\
\text { association }\end{array}$ \\
\hline $\begin{array}{l}\text { Clarke } \\
\text { et al. } \\
{[15]}\end{array}$ & 2013 & Prospective & $\begin{array}{l}\text { Female, } n= \\
\quad 3,737\end{array}$ & Genital & Yes & $\begin{array}{c}1,491 / 3,225 \\
(46.2 \%) \\
{[50.7 \text { months }]}\end{array}$ & $\begin{array}{l}317 / 499 \\
\quad(63.5 \%) \\
{[50.7 \text { months }]}\end{array}$ & $\begin{array}{l}\mathrm{HR}=1.2 ; \\
95 \% \mathrm{CI} \\
1.0-1.3\end{array}$ & $\begin{array}{l}\text { Evaluation of high-risk } \\
\text { HPV infection }\end{array}$ \\
\hline $\begin{array}{l}\text { Schabath } \\
\text { et al. } \\
\text { [16] }\end{array}$ & 2013 & Prospective & $\begin{array}{c}\text { Male, } n= \\
4,026\end{array}$ & Genital & Yes & $\begin{array}{c}812 / 2,326 \\
(34.9 \%) \\
{[12 \text { months }]}\end{array}$ & $\begin{array}{l}399 / 948 \\
(42.1 \%) \\
{[12 \text { months }]}\end{array}$ & $\begin{array}{l}\mathrm{HR}=1.2 ; \\
\quad 95 \% \mathrm{CI} \\
1.0-1.5\end{array}$ & $\begin{array}{l}\text { Significantly higher } \\
\text { association for current } \\
\text { smokers compared to } \\
\text { former and never } \\
\text { smokers }\end{array}$ \\
\hline $\begin{array}{l}\text { Nyitray } \\
\quad \text { et al. } \\
{[27]}\end{array}$ & 2011 & Prospective & $\begin{array}{c}\text { Male, } n= \\
1,110\end{array}$ & Anogenital & (Yes) & - & - & - & $\begin{array}{l}\text { Association in bivariate } \\
\text { analysis among men } \\
\text { who have sex with } \\
\text { women }\end{array}$ \\
\hline $\begin{array}{l}\text { Nielsen } \\
\text { et al. } \\
{[18]}\end{array}$ & 2009 & Prospective & $\begin{array}{l}\text { Female, } n= \\
\quad 7,454\end{array}$ & Genital & Yes & - & - & $\begin{array}{l}\mathrm{OR}=1.5 \\
95 \% \mathrm{CI} \\
1.2-1.9\end{array}$ & $\begin{array}{l}\text { Association for } \\
\text { acquiring a single } \\
\text { high-risk HPV } \\
\text { infection ( } \geq 10 \\
\text { cigarettes per day) }\end{array}$ \\
\hline $\begin{array}{l}\text { Sarian } \\
\text { et al. } \\
\text { [19] }\end{array}$ & 2009 & Prospective & $\begin{array}{c}\text { Female, } n= \\
12,114\end{array}$ & Genital & Yes & - & - & $\begin{array}{l}\mathrm{OR}=1.6 \\
95 \% \mathrm{CI} \\
1.2-2.1\end{array}$ & $\begin{array}{l}\text { Evaluation of high-risk } \\
\text { HPV infection }\end{array}$ \\
\hline $\begin{array}{l}\text { Goodman } \\
\text { et al. } \\
\text { [28] }\end{array}$ & 2008 & Prospective & $\begin{array}{l}\text { Female, } n= \\
\quad 431\end{array}$ & Anal & No & $\begin{array}{l}137 / 276 \\
\quad(49.6 \%) \\
{[16 \text { months }]}\end{array}$ & $\begin{array}{l}29 / 61 \\
\quad(47.5 \%) \\
{[16 \text { months }]}\end{array}$ & $\begin{array}{l}\mathrm{OR}=0.9 \\
95 \% \mathrm{CI} \\
0.5-1.6\end{array}$ & \\
\hline $\begin{array}{l}\text { Oh et al. } \\
{[20]}\end{array}$ & 2008 & Prospective & $\begin{array}{l}\text { Female, } n= \\
\quad 197\end{array}$ & Genital & (Yes) & $\begin{array}{l}16 / 131 \\
\quad(12.2 \%) \\
{[18 \text { months }]}\end{array}$ & $\begin{array}{l}5 / 12(41.7 \%) \\
{[18 \text { months }]}\end{array}$ & $\begin{array}{l}\mathrm{OR}=3.3 \\
95 \% \mathrm{CI} \\
0.7- \\
14.6\end{array}$ & $\begin{array}{l}\text { Statistically } \\
\text { nonsignificant trend }\end{array}$ \\
\hline $\begin{array}{l}\text { Partridge } \\
\text { et al. } \\
\text { [21] }\end{array}$ & 2007 & Prospective & $\begin{array}{l}\text { Male, } n= \\
\quad 240\end{array}$ & Genital & Yes & - & - & $\begin{array}{l}\mathrm{HR}=1.0 \\
\quad 95 \% \mathrm{CI} \\
0.4-2.2\end{array}$ & $\begin{array}{l}\text { Association with past } \\
\text { smoking but not with } \\
\text { current smoking }\end{array}$ \\
\hline $\begin{array}{l}\text { Syrjänen } \\
\text { et al. } \\
\text { [22] }\end{array}$ & 2007 & Prospective & $\begin{array}{l}\text { Female, } n= \\
\quad 3187\end{array}$ & Genital & Yes & - & - & $\begin{array}{l}\mathrm{OR}=1.5 \\
95 \% \mathrm{CI} \\
1.1-2.1\end{array}$ & $\begin{array}{l}\text { Evaluation of high-risk } \\
\text { HPV infection }\end{array}$ \\
\hline $\begin{array}{l}\text { Kjaer } \\
\quad \text { et al. } \\
{[23]}\end{array}$ & 2005 & Prospective & $\begin{array}{l}\text { Male, } n= \\
\quad 374\end{array}$ & Genital & No & $\begin{array}{l}17 / 102 \\
(16.7 \%) \\
{[7 \text { months }]}\end{array}$ & $\begin{array}{l}6 / 42(14.3 \%) \\
{[7 \text { months }]}\end{array}$ & $\begin{array}{l}\mathrm{OR}=0.6 \\
95 \% \mathrm{CI} \\
0.2-2.0\end{array}$ & \\
\hline $\begin{array}{c}\text { Minkoff } \\
\text { et al. } \\
{[24]}\end{array}$ & 2004 & Prospective & $\begin{array}{l}\text { Female, } n= \\
\quad 2293\end{array}$ & Genital & (Yes) & - & - & - & $\begin{array}{l}\text { Association in HIV- } \\
\text { infected but not in } \\
\text { HIV-uninfected } \\
\text { women }\end{array}$ \\
\hline $\begin{array}{l}\text { Sellors } \\
\text { et al. } \\
{[25]}\end{array}$ & 2003 & Prospective & $\begin{array}{l}\text { Female, } n= \\
\quad 307\end{array}$ & Genital & No & $\begin{array}{l}19 / 178 \\
\quad(10.7 \%) \\
{[14 \text { months }]}\end{array}$ & $\begin{array}{l}\text { 9/72 (12.5\%) } \\
{[14 \text { months] }}\end{array}$ & $\begin{array}{c}\mathrm{OR}=0.6 \\
95 \% \mathrm{CI} \\
0.2-1.9\end{array}$ & $\begin{array}{l}\text { Evaluation of high-risk } \\
\text { HPV infection }\end{array}$ \\
\hline $\begin{array}{l}\text { Winer } \\
\text { et al. } \\
{[26]}\end{array}$ & 2003 & Prospective & $\begin{array}{l}\text { Female, } n= \\
\quad 603\end{array}$ & Genital & Yes & - & - & $\begin{array}{l}\mathrm{HR}=1.5 ; \\
\quad 95 \% \mathrm{CI} \\
1.0-2.3\end{array}$ & $\begin{array}{l}\text { Association with current } \\
\text { smoking }\end{array}$ \\
\hline $\begin{array}{l}\text { Moscicki } \\
\text { et al. } \\
\text { [29] }\end{array}$ & 2001 & Prospective & $\begin{array}{l}\text { Female, } n= \\
\quad 601\end{array}$ & Genital & No & - & - & - & \\
\hline
\end{tabular}

$O R$ odds ratio, $H R$ hazard ratio

and the persistence rate of $\operatorname{HPV}[37,35]$. Interestingly, Ho et al. even found that smoking $>5$ cigarettes per day was protective against persistent $\mathrm{HPV}$ infection $(\mathrm{OR}=0.3,95 \%$ CI 0.2-0.7) [35]. 


\section{Prevalence of HPV}

With respect to the prevalence of anogenital HPV, most studies showed an association with smoking for both men and women. Forty-seven studies (four prospective [40, 19, 41, 24], one retrospective [42], and 42 cross-sectional [43-68, 14, 69-83] studies) - including a total of 83,480 patients - found a significant association (35 studies [19, 40-44, 46, 48-53, $55-59,61-64,66-68,14,69-71,75-77,79,80,83])$ with smoking or a trend (12 studies [24, 45, 47, 54, 65, 72-74, $60,78,81,82])$ toward an association, whereas 16 studies (one prospective [84] and 15 cross-sectional [17, 85-98] studies) - with a total of 12,188 patients - did not. Four out of five prospective studies - including 19,581 patients - found a significant association (three studies) between HPV prevalence and smoking or a trend (one study) toward higher rates among smokers compared to nonsmokers (Table 2) [40, 19, 41, 24]. The remaining prospective study with 576 patients did not reveal an association [84].

A statistical analysis of all prospective studies evaluating association between the prevalence of HPV and smoking showed that the overall HPV prevalence for smoking patients was 48.2 versus $37.5 \%$ for nonsmoking patients $(p<0.001)$
$(\mathrm{OR}=1.5,95 \%$ CI 1.4-1.7). For female patients only, the prevalence was $40.8 \%$ for smokers versus $25.2 \%$ for nonsmokers $(p<0.001)(\mathrm{OR}=2.0,95 \%$ CI 1.8-2.3) and for male patients 68.2 versus $63.2 \%(p=0.006)(\mathrm{OR}=1.2,95 \% \mathrm{CI}$ 1.1-1.5).

There are ten studies comparing current with past smoking with regard to the prevalence of HPV [49, 51, 40, 61, 19, 14, 69, 72, 77, 90]. Except for one study, no impact of past smoking on the prevalence of HPV was shown [49, 51, 40, 61, 19, 14, 69, 72, 77].

Four cross-sectional studies among current smokers showed increasing prevalence of HPV with the number of cigarettes smoked [49, 50, 14, 69]. Nielson et al. found a stronger association between HPV detection and smoking $\geq 10$ cigarettes than for smoking $<10$ cigarettes per day $(\mathrm{OR}=2.3,95 \%$ CI 1.0-5.3) [69]. In contrast, Roura et al. and Schabath et al. did not find any impact of the intensity of smoking on the prevalence of HPV [51, 40].

\section{High-risk HPV}

Four prospective studies focused on the incidence of high-risk HPV infection [15, 19, 22, 18]. These investigators

Table 2 Summary of all prospective studies evaluating the association between the prevalence of HPV and smoking

\begin{tabular}{|c|c|c|c|c|c|c|c|c|c|}
\hline Author & $\begin{array}{l}\text { Publication } \\
\text { year }\end{array}$ & $\begin{array}{l}\text { Study } \\
\text { design }\end{array}$ & $\begin{array}{l}\text { Population } \\
\text { (sex, } \\
\text { number of } \\
\text { patients } \\
\text { included) }\end{array}$ & Localization & $\begin{array}{l}\text { Association } \\
\text { with } \\
\text { smoking }\end{array}$ & $\begin{array}{l}\text { HPV } \\
\text { prevalence } \\
\text { in } \\
\text { nonsmoking } \\
\text { subjects }\end{array}$ & $\begin{array}{l}\text { HPV } \\
\text { prevalence } \\
\text { in currently } \\
\text { smoking } \\
\text { subjects }\end{array}$ & $\begin{array}{l}\text { OR or HR } \\
\text { for } \\
\text { currently } \\
\text { smoking } \\
\text { subjects }\end{array}$ & $\begin{array}{l}\text { Specification of the } \\
\text { association }\end{array}$ \\
\hline $\begin{array}{l}\text { Schabath } \\
\text { et al. } \\
\text { [40] }\end{array}$ & 2012 & Prospective & $\begin{array}{c}\text { Male, } n= \\
4,054\end{array}$ & Genital & Yes & $\begin{array}{c}1,485 / 2,348 \\
(63.2 \%)\end{array}$ & $\begin{array}{l}655 / 960 \\
\quad(68.2 \%)\end{array}$ & $\begin{array}{l}\mathrm{OR}=1.2 \\
95 \% \\
\text { CI } 1.0- \\
1.4\end{array}$ & $\begin{array}{l}\text { Association with current but } \\
\text { not past smokers. No } \\
\text { association between } \\
\text { intensity of smoking and } \\
\text { HPV prevalence }\end{array}$ \\
\hline $\begin{array}{l}\text { Sarian et al. } \\
\text { [19] }\end{array}$ & 2009 & Prospective & $\begin{array}{c}\text { Female, } n= \\
12,114\end{array}$ & Genital & Yes & $\begin{array}{l}444 / 2,699 \\
\quad(16.5 \%)\end{array}$ & $\begin{array}{l}215 / 990 \\
\quad(21.7 \%)\end{array}$ & $\begin{array}{l}\mathrm{OR}=1.6 \\
95 \% \\
\text { CI } 1.2- \\
2.1\end{array}$ & $\begin{array}{l}\text { Evaluation of high-risk HPV } \\
\text { infection. Association } \\
\text { with current but not past } \\
\text { smokers }\end{array}$ \\
\hline $\begin{array}{l}\text { Kliucinskas } \\
\text { et al. } \\
\text { [41] }\end{array}$ & 2006 & Prospective & $\begin{array}{c}\text { Female, } n= \\
1,120\end{array}$ & Genital & Yes & $\begin{array}{l}109 / 892 \\
\quad(12.2 \%)\end{array}$ & $\begin{array}{l}25 / 128 \\
\quad(19.5 \%)\end{array}$ & $\begin{array}{l}\mathrm{OR}=1.8 \\
95 \% \\
\text { CI } 1.2- \\
2.8\end{array}$ & $\begin{array}{l}\text { Evaluation of high-risk HPV } \\
\text { infection }\end{array}$ \\
\hline $\begin{array}{l}\text { Minkoff } \\
\text { et al. } \\
\text { [24] }\end{array}$ & 2004 & Prospective & $\begin{array}{c}\text { Female, } n= \\
2,293\end{array}$ & Genital & (Yes) & $\begin{array}{l}516 / 966 \\
\quad(53.4 \%)\end{array}$ & $\begin{array}{l}735 / 1,294 \\
(56.8 \%)\end{array}$ & $\begin{array}{l}\mathrm{OR}=1.1 \\
95 \% \\
\text { CI } 1.0- \\
1.4\end{array}$ & $\begin{array}{l}\text { Association in HIV-infected } \\
\text { but not in HIV-uninfected } \\
\text { women }\end{array}$ \\
\hline $\begin{array}{l}\text { Feldman } \\
\text { et al. } \\
\text { [84] }\end{array}$ & 1997 & Prospective & $\begin{array}{l}\text { Female, } n= \\
576\end{array}$ & Genital & No & $\begin{array}{l}174 / 370 \\
\quad(47.0 \%)\end{array}$ & $\begin{array}{l}93 / 206 \\
\quad(45.1 \%)\end{array}$ & $\begin{array}{c}\mathrm{OR}=0.9 \\
95 \% \\
\text { CI } 0.7- \\
1.3\end{array}$ & \\
\hline Total & & & & & & $\begin{array}{c}2,728 / 7,275 \\
(37.5 \%)\end{array}$ & $\begin{array}{l}1,723 / \\
3,578 \\
(48.2 \%)\end{array}$ & $\begin{array}{l}\mathrm{OR}=1.5 \\
95 \% \\
\text { CI } 1.4- \\
1.7\end{array}$ & \\
\hline
\end{tabular}

$O R$ odds ratio, $H R$ hazard ratio 
consistently found a significant association between smoking and high-risk HPV incidence.

Regarding persistence of high-risk HPV infection, three out of four prospective studies with a total of 827 patients revealed a significant association with smoking [32, 39, 38], whereas one study with 7,418 patients did not [37].

An analysis of HPV types in female patients revealed no significant difference in prevalence of high- or low-risk HPV genotypes when comparing female smokers to nonsmokers
[99]. In two prospective studies including a total of 13,234 patients, a significant impact of smoking on the prevalence of high-risk HPV was found [19, 41].

Development of anogenital warts

Smoking has been shown to significantly increase the incidence of anogenital warts (Table 3). The risk of developing anogenital warts increases with the number

Table 3 Summary of all published studies evaluating the association between the incidence of anogenital warts and smoking

\begin{tabular}{|c|c|c|c|c|c|c|c|c|c|}
\hline Author & $\begin{array}{l}\text { Publication } \\
\text { year }\end{array}$ & Study design & $\begin{array}{l}\text { Population } \\
\text { (sex, } \\
\text { number of } \\
\text { patients } \\
\text { included) }\end{array}$ & Localization & $\begin{array}{l}\text { Association } \\
\text { with } \\
\text { smoking }\end{array}$ & $\begin{array}{l}\text { Incidence of } \\
\text { anogenital } \\
\text { warts in } \\
\text { nonsmoking } \\
\text { subjects }\end{array}$ & $\begin{array}{l}\text { Incidence of } \\
\text { anogenital } \\
\text { warts in } \\
\text { currently } \\
\text { smoking } \\
\text { subjects }\end{array}$ & $\begin{array}{l}\text { OR or HR } \\
\text { for } \\
\text { currently } \\
\text { smoking } \\
\text { subjects }\end{array}$ & $\begin{array}{l}\text { Specification of the } \\
\text { association }\end{array}$ \\
\hline $\begin{array}{l}\text { Massad } \\
\text { et al. } \\
{[103]}\end{array}$ & 2011 & Prospective & $\begin{array}{l}\text { Female, } \\
\qquad n=3766\end{array}$ & Genital & Yes & - & - & $\begin{array}{l}\mathrm{HR}=1.8 \\
95 \% \\
\text { CI } 1.4- \\
2.4\end{array}$ & $\begin{array}{l}\text { Association with current } \\
\text { but not with former } \\
\text { smoking }\end{array}$ \\
\hline $\begin{array}{l}\text { Wiley } \\
\text { et al. } \\
{[113]}\end{array}$ & 2009 & Prospective & $\begin{array}{l}\text { Male, } n= \\
\quad 2835\end{array}$ & Genital & Yes & - & - & - & \\
\hline $\begin{array}{l}\text { Massad } \\
\text { et al. } \\
{[104]}\end{array}$ & 2004 & Prospective & $\begin{array}{l}\text { Female, } \\
\qquad n=2031\end{array}$ & Genital & Yes & - & - & - & $\begin{array}{l}\text { Association with current } \\
\text { but not with former } \\
\text { smoking }\end{array}$ \\
\hline $\begin{array}{l}\text { Feldman } \\
\text { et al. } \\
\text { [84] }\end{array}$ & 1997 & Prospective & $\begin{array}{l}\text { Female, } \\
\qquad n=576\end{array}$ & Genital & Yes & - & - & - & \\
\hline $\begin{array}{l}\text { Hansen } \\
\text { et al. } \\
{[102]}\end{array}$ & 2010 & Retrospective & $\begin{array}{l}\text { Female, } \\
\quad \begin{array}{l}n= \\
58094\end{array}\end{array}$ & Genital & Yes & - & - & $\begin{array}{l}\mathrm{HR}=1.3 \\
95 \% \\
\text { CI } 1.2- \\
1.4 .\end{array}$ & $\begin{array}{l}\text { Increasing risk with } \\
\text { increasing number of } \\
\text { cigarettes smoked per } \\
\text { day }\end{array}$ \\
\hline $\begin{array}{l}\text { Kjaer } \\
\quad \text { et al. } \\
{[114]}\end{array}$ & 2007 & Retrospective & $\begin{array}{l}\text { Female, } \\
\qquad \begin{array}{l}n= \\
69147\end{array}\end{array}$ & Genital & Yes & $\begin{array}{l}2,936 / 35,799 \\
\quad(8.2 \%)\end{array}$ & $\begin{array}{c}2,251 / 15,965 \\
(14.1 \%)\end{array}$ & $\begin{array}{l}\mathrm{OR}=1.1 \\
95 \% \\
\text { CI } 1.0- \\
1.2\end{array}$ & $\begin{array}{l}\text { Association with smoking } \\
\text { for }>59 \text { pack-years }\end{array}$ \\
\hline $\begin{array}{l}\text { Wen } \\
\text { et al. } \\
\text { [13] }\end{array}$ & 1999 & Retrospective & $\begin{array}{l}\text { Male and } \\
\text { female, } \\
n=1954\end{array}$ & Genital & Yes & $\begin{array}{l}89 / 631 \\
\quad(14.1 \%)\end{array}$ & $\begin{array}{l}154 / 644 \\
\quad(23.9 \%)\end{array}$ & $\begin{array}{l}\mathrm{OR}=1.9 \\
95 \% \\
\text { CI } 1.0- \\
2.3\end{array}$ & $\begin{array}{l}\text { Smokers of more than } 10 \\
\text { cigarettes per day were } \\
\text { twice as likely to have } \\
\text { genital warts as were } \\
\text { nonsmokers }\end{array}$ \\
\hline $\begin{array}{l}\text { Habel } \\
\qquad \text { et al. } \\
{[106]}\end{array}$ & 1998 & Retrospective & $\begin{array}{l}\text { Female, } \\
\quad n=282\end{array}$ & Anogenital & (Yes) & $\begin{array}{l}45 / 118 \\
\quad(38.1 \%)\end{array}$ & $\begin{array}{l}35 / 67 \\
\quad(52.2 \%)\end{array}$ & $\begin{array}{l}\mathrm{OR}=1.8 \\
95 \% \\
\text { CI } 1.0- \\
3.3\end{array}$ & $\begin{array}{l}\text { Statistically nonsignificant } \\
\text { association }\end{array}$ \\
\hline $\begin{array}{l}\text { Munk } \\
\text { et al. } \\
{[100]}\end{array}$ & 1997 & Retrospective & $\begin{array}{l}\text { Female, } \\
\qquad \begin{array}{l}n= \\
10838\end{array}\end{array}$ & Genital & Yes & - & - & $\begin{array}{l}\mathrm{OR}=1.5 \\
95 \% \\
\text { CI } 1.2- \\
1.8\end{array}$ & $\begin{array}{l}\text { Increasing risk with } \\
\text { increasing pack-years } \\
\text { of cigarette smoking }\end{array}$ \\
\hline $\begin{array}{l}\text { Brisson } \\
\text { et al. } \\
{[101]}\end{array}$ & 1988 & Retrospective & $\begin{array}{l}\text { Female, } \\
\quad n=520\end{array}$ & Genital & Yes & - & - & - & $\begin{array}{l}\text { Increasing risk with } \\
\text { increasing number of } \\
\text { cigarettes smoked per } \\
\text { day }\end{array}$ \\
\hline $\begin{array}{l}\text { Daling } \\
\text { et al. } \\
{[115]}\end{array}$ & 1986 & Retrospective & $\begin{array}{l}\text { Female, } \\
\quad n=245\end{array}$ & Anogenital & Yes & - & - & - & \\
\hline
\end{tabular}

$O R$ odds ratio, $H R$ hazard ratio 
of cigarettes smoked per day and the number of packyears [13, 100-102]. However, this association only applies to current but not to past smoking [103, 104]. Luu et al. investigated the impact of current smoking on the size of anal warts but failed to find a relationship [105]. Smoking for 10 or more years has been found to increase the risk of recurrent genital warts (relative risk $(\mathrm{RR})=4.5,95 \%$ CI 1.4-13.8) [106].

\section{Discussion}

In both genders, smoking is associated with higher incidence and prevalence rates for HPV infection, whereas the latter responds to a dose-effect relationship. Smoking does also increase persistence rates for highrisk HPV infection, while this correlation is debatable for low-risk HPV. The incidence and recurrence rates of anogenital warts are significantly increased in current smokers.

Smoking has deleterious effects on systemic and local immunity, as it suppresses both cell-mediated and humoral immune responses, which might lead to the present finding of increased susceptibility to HPV infection and development of anogenital warts [107]. Nicotine, the addictive substance in cigarette smoke, has been shown to be the main immunosuppressive constituent of cigarette smoke [107]. Moreover, smoking has been found to increase metaplasia and DNA damage in various tissues [108-111].

Although most studies adjusted for sexual behavior, unmeasured high-risk sexual behavior might be a potentially important confounder in the association between smoking and the incidence of HPV infection [16, 15, 26]. This is supported by Herrero et al., who found that sex with multiple partners is more prevalent among smokers [112].

The prevalence of HPV infection seems to decrease in patients who quit smoking, but the time period after which nonsmoker levels are reached is not yet clear.

The association of smoking with HPV infection and development of anogenital warts, respectively, is well supported by current data. However, the cascade from HPV infection to the development of anogenital warts is still not well understood. Furthermore, prospective data on the impact of smoking on the spontaneous recovery rate of anogenital warts are still lacking.

Studies are more often performed for female than male patients, probably due to regular gynecologic controls. On the other hand, comparison of the studies did not reveal gender differences in the impact of smoking.

\section{Conclusion}

Most current data demonstrate an association between smoking, increased anogenital HPV infection, and development of anogenital warts. These data add to the long list of reasons for making smoking cessation a keystone of patient health.

\section{References}

1. WHO Vaccines against human papilloma virus. http://www.who. int/vaccines/en/hpvrd.shtml. Accessed April 01, 2014

2. Forcier M, Musacchio N (2010) An overview of human papillomavirus infection for the dermatologist: disease, diagnosis, management, and prevention. Dermatol Ther 23(5):458-476. doi:10.1111/j. 1529-8019.2010.01350.x

3. Markowitz LE, Dunne EF, Saraiya M, Lawson HW, Chesson H, Unger ER (2007) Quadrivalent human papillomavirus vaccine: recommendations of the Advisory Committee on Immunization Practices (ACIP). MMWR Recommendations and reports: Morbidity and mortality weekly report Recommendations and reports / Centers for Disease Control 56 (Rr-2):1-24

4. Hathaway JK (2012) HPV: diagnosis, prevention, and treatment. Clin Obstet Gynecol 55(3):671-680. doi:10.1097/GRF. 0b013e31825caa36

5. Fleischer AB Jr, Parrish CA, Glenn R, Feldman SR (2001) Condylomata acuminata (genital warts): patient demographics and treating physicians. Sex Transm Dis 28(11):643-647

6. Stanley M (2007) Prophylactic HPV vaccines: prospects for eliminating ano-genital cancer. Br J Cancer 96(9):1320-1323. doi:10. 1038/sj.bjc.6603695

7. Gross G, Pfister H (2004) Role of human papillomavirus in penile cancer, penile intraepithelial squamous cell neoplasias and in genital warts. Med Microbiol Immunol 193(1):35-44. doi:10.1007/ s00430-003-0181-2

8. Tay EH, Garland S, Tang G, Nolan T, Huang LM, Orloski L, Lu S, Barr E (2008) Clinical trial experience with prophylactic HPV 6/11/ $16 / 18$ VLP vaccine in young women from the Asia-Pacific region. Int J Gynaecol Obstet Off Organ Int Fed Gynaecol Obstet 102(3): 275-283. doi:10.1016/j.ijgo.2008.03.021

9. Patel H, Wagner M, Singhal P, Kothari S (2013) Systematic review of the incidence and prevalence of genital warts. BMC Infect Dis 13:39. doi:10.1186/1471-2334-13-39

10. Scheinfeld N, Lehman DS (2006) An evidence-based review of medical and surgical treatments of genital warts. Dermatol Online J 12(3):5

11. Wiley DJ, Douglas J, Beutner K, Cox T, Fife K, Moscicki AB, Fukumoto L (2002) External genital warts: diagnosis, treatment, and prevention. Clin Infect Dis Off Publ Infect Dis Soc Am 35(Suppl 2): S210-S224. doi:10.1086/342109

12. Kodner CM, Nasraty S (2004) Management of genital warts. Am Fam Physician 70(12):2335-2342

13. Wen LM, Estcourt CS, Simpson JM, Mindel A (1999) Risk factors for the acquisition of genital warts: are condoms protective? Sex Transm Infect 75(5):312-316

14. Vaccarella S, Herrero R, Snijders PJ, Dai M, Thomas JO, Hieu NT, Ferreccio C, Matos E, Posso H, de Sanjose S, Shin HR, Sukvirach S, Lazcano-Ponce E, Munoz N, Meijer CJ, Franceschi S (2008) Smoking and human papillomavirus infection: pooled analysis of 
the International Agency for Research on Cancer HPV Prevalence Surveys. Int J Epidemiol 37(3):536-546. doi:10.1093/ije/dyn033

15. Clarke M, Schiffman M, Wacholder S, Rodriguez AC, Hildesheim A, Quint W (2013) A prospective study of absolute risk and determinants of human papillomavirus incidence among young women in Costa Rica. BMC Infect Dis 13:308. doi:10.1186/1471-2334-13308

16. Schabath MB, Villa LL, Lin HY, Fulp WJ, Lazcano-Ponce E, Salmeron J, Abrahamsen ME, Papenfuss MR, Quiterio M, Giuliano AR (2013) A prospective analysis of smoking and human papillomavirus infection among men in the HPV in Men Study. Int J Cancer J Int Cancer. doi:10.1002/ijc.28567

17. Almonte M, Silva Idos S, Asare A, Gilham C, Sargent A, Bailey A, Turner A, Desai M, Kitchener HC, Peto J (2011) Sexual behavior and HPV infection in British women, by postal questionnaires and telephone interviews. J Med Virol 83(7):1238-1246. doi:10.1002/ jmv. 22085

18. Nielsen A, Iftner T, Munk C, Kjaer SK (2009) Acquisition of highrisk human papillomavirus infection in a population-based cohort of Danish women. Sex Transm Dis 36(10):609-615. doi:10.1097/ OLQ.0b013e3181a96d0e

19. Sarian LO, Hammes LS, Longatto-Filho A, Guarisi R, Derchain SF, Roteli-Martins C, Naud P, Erzen M, Branca M, Tatti S, de Matos JC, Gontijo R, Maeda MY, Lima T, Costa S, Syrjanen S, Syrjanen K (2009) Increased risk of oncogenic human papillomavirus infections and incident high-grade cervical intraepithelial neoplasia among smokers: experience from the Latin American screening study. Sex Transm Dis 36(4):241-248. doi:10.1097/OLQ. 0b013e3181935a7d

20. Oh JK, Ju YH, Franceschi S, Quint W, Shin HR (2008) Acquisition of new infection and clearance of type-specific human papillomavirus infections in female students in Busan, South Korea: a followup study. BMC Infect Dis 8:13. doi:10.1186/1471-2334-8-13

21. Partridge JM, Hughes JP, Feng Q, Winer RL, Weaver BA, Xi LF, Stern ME, Lee SK, O'Reilly SF, Hawes SE, Kiviat NB, Koutsky LA (2007) Genital human papillomavirus infection in men: incidence and risk factors in a cohort of university students. J Infect Dis 196(8):1128-1136. doi:10.1086/521192

22. Syrjanen K, Shabalova I, Petrovichev N, Kozachenko V, Zakharova T, Pajanidi J, Podistov J, Chemeris G, Sozaeva L, Lipova E, Tsidaeva I, Ivanchenko O, Pshepurko A, Zakharenko S, Nerovjna R, Kljukina L, Erokhina O, Branovskaja M, Nikitina M, Grunberga V, Grunberg A, Juschenko A, Santopietro R, Cintorino M, Tosi P, Syrjanen S (2007) Smoking is an independent risk factor for oncogenic human papillomavirus (HPV) infections but not for highgrade CIN. Eur J Epidemiol 22(10):723-735. doi:10.1007/ s10654-007-9180-8

23. Kjaer SK, Munk C, Winther JF, Jorgensen HO, Meijer CJ, van den Brule AJ (2005) Acquisition and persistence of human papillomavirus infection in younger men: a prospective follow-up study among Danish soldiers. Cancer Epidemiol Biomark Prev Publ Am Assoc Cancer Res Cosponsored Am Soc Prev Oncol 14(6):15281533. doi:10.1158/1055-9965.epi-04-0754

24. Minkoff H, Feldman JG, Strickler HD, Watts DH, Bacon MC, Levine A, Palefsky JM, Burk R, Cohen MH, Anastos K (2004) Relationship between smoking and human papillomavirus infections in HIV-infected and -uninfected women. J Infect Dis 189(10): 1821-1828. doi:10.1086/383479

25. Sellors JW, Karwalajtys TL, Kaczorowski J, Mahony JB, Lytwyn A, Chong S, Sparrow J, Lorincz A (2003) Incidence, clearance and predictors of human papillomavirus infection in women. CMAJ: Can Med Assoc J 168(4):421-425

26. Winer RL, Lee SK, Hughes JP, Adam DE, Kiviat NB, Koutsky LA (2003) Genital human papillomavirus infection: incidence and risk factors in a cohort of female university students. Am J Epidemiol 157(3):218-226
27. Nyitray AG, Carvalho da Silva RJ, Baggio ML, Smith D, Abrahamsen M, Papenfuss M, Lin HY, Quiterio M, Salmeron J, Lazcano-Ponce E, Villa LL, Giuliano AR (2011) Six-month incidence, persistence, and factors associated with persistence of anal human papillomavirus in men: the HPV in men study. J Infect Dis 204(11):1711-1722. doi:10.1093/infdis/jir637

28. Goodman MT, Shvetsov YB, McDuffie K, Wilkens LR, Zhu X, Ning L, Killeen J, Kamemoto L, Hernandez BY (2008) Acquisition of anal human papillomavirus (HPV) infection in women: the Hawaii HPV cohort study. J Infect Dis 197(7):957-966. doi:10. $1086 / 529207$

29. Moscicki AB, Hills N, Shiboski S, Powell K, Jay N, Hanson E, Miller S, Clayton L, Farhat S, Broering J, Darragh T, Palefsky J (2001) Risks for incident human papillomavirus infection and lowgrade squamous intraepithelial lesion development in young females. JAMA: J Am Med Assoc 285(23):2995-3002

30. Kjaer SK, Breugelmans G, Munk C, Junge J, Watson M, Iftner T (2008) Population-based prevalence, type- and age-specific distribution of HPV in women before introduction of an HPV-vaccination program in Denmark. Int J Cancer 123(8):1864-1870. doi:10.1002/ ijc. 23712

31. Shvetsov YB, Hernandez BY, McDuffie K, Wilkens LR, Zhu X, Ning L, Killeen J, Kamemoto L, Goodman MT (2009) Duration and clearance of anal human papillomavirus (HPV) infection among women: the Hawaii HPV cohort study. Clin Infect Dis: Off Publ Infect Dis Soc Am 48(5):536-546. doi:10.1086/596758

32. Schmeink CE, Melchers WJ, Siebers AG, Quint WG, Massuger LF, Bekkers RL (2011) Human papillomavirus persistence in young unscreened women, a prospective cohort study. PLoS One 6(11): e27937. doi:10.1371/journal.pone.0027937

33. Maucort-Boulch D, Plummer M, Castle PE, Demuth F, Safaeian M, Wheeler CM, Schiffman M (2010) Predictors of human papillomavirus persistence among women with equivocal or mildly abnormal cytology. Int J Cancer 126(3):684-691. doi:10.1002/ijc.24752

34. Koshiol J, Schroeder J, Jamieson DJ, Marshall SW, Duerr A, Heilig CM, Shah KV, Klein RS, Cu-Uvin S, Schuman P, Celentano D, Smith JS (2006) Smoking and time to clearance of human papillomavirus infection in HIV-seropositive and HIV-seronegative women. Am J Epidemiol 164(2):176-183. doi:10.1093/aje/kwj165

35. Ho GY, Bierman R, Beardsley L, Chang CJ, Burk RD (1998) Natural history of cervicovaginal papillomavirus infection in young women. N Engl J Med 338(7):423-428. doi:10.1056/ nejm199802123380703

36. Louvanto K, Rintala MA, Syrjanen KJ, Grenman SE, Syrjanen SM (2010) Genotype-specific persistence of genital human papillomavirus (HPV) infections in women followed for 6 years in the Finnish Family HPV Study. J Infect Dis 202(3):436-444. doi:10.1086/ 653826

37. Nielsen A, Kjaer SK, Munk C, Osler M, Iftner T (2010) Persistence of high-risk human papillomavirus infection in a population-based cohort of Danish women. J Med Virol 82(4):616-623. doi:10.1002/ jmv. 21750

38. Phanuphak N, Teeratakulpisarn N, Pankam T, Kerr SJ, Barisri J, Deesua A, Rodbamrung P, Hongchookiat P, Chomchey N, Phanuphak P, Sohn AH, Ananworanich J, Palefsky JM (2013) Anal human papillomavirus infection among Thai men who have sex with men with and without HIV infection: prevalence, incidence, and persistence. J Acquir Immune Defic Syndr 63(4):472479. doi:10.1097/QAI.0b013e3182918a5a

39. Giuliano AR, Sedjo RL, Roe DJ, Harri R, Baldwi S, Papenfuss MR, Abrahamsen M, Inserra P (2002) Clearance of oncogenic human papillomavirus (HPV) infection: effect of smoking (United States). Cancer Causes Control: CCC 13(9):839-846

40. Schabath MB, Villa LL, Lazcano-Ponce E, Salmeron J, Quiterio M, Giuliano AR (2012) Smoking and human papillomavirus (HPV) infection in the HPV in Men (HIM) study. Cancer Epidemiol 
Biomark Prev: Publ Am Assoc Cancer Res Cosponsored Am Soc Prev Oncol 21(1):102-110. doi:10.1158/1055-9965.epi-11-0591

41. Kliucinskas M, Nadisauskiene RJ, Minkauskiene M (2006) Prevalence and risk factors of HPV infection among high-risk rural and urban Lithuanian women. Gynecol Obstet Investig 62(3):173180. doi:10.1159/000093572

42. Kataja V, Syrjanen S, Yliskoski M, Hippelinen M, Vayrynen M, Saarikoski S, Mantyjarvi R, Jokela V, Salonen JT, Syrjanen K (1993) Risk factors associated with cervical human papillomavirus infections: a case-control study. Am J Epidemiol 138(9):735-745

43. Hoang HT, Ishizaki A, Nguyen CH, Tran VT, Matsushita K, Saikawa K, Hosaka N, Pham HV, Bi X, Ta VT, Van Pham T, Ichimura H (2013) Infection with high-risk HPV types among female sex workers in northern Vietnam. J Med Virol 85(2):288294. doi:10.1002/jmv.23456

44. Nielsen A, Munk C, Jorgensen H, Winther J, van den Brule A, Kjaer S (2013) Multiple-type human papillomavirus infection in younger uncircumcised men. Int J STD AIDS. doi:10.1177/ 0956462412472294

45. Remschmidt C, Kaufmann AM, Hagemann I, Vartazarova E, Wichmann O, Delere Y (2013) Risk factors for cervical human papillomavirus infection and high-grade intraepithelial lesion in women aged 20 to 31 years in Germany. Int J Gynecol Cancer: Off J Int Gynecol Cancer Soc 23(3):519-526. doi:10.1097/IGC. 0b013e318285a4b2

46. Brassard P, Jiang Y, Severini A, Goleski V, Santos M, Chatwood S, Lys C, Johnson G, Wong T, Kotaska A, Kandola K, Morrison H, Mao Y (2012) Factors associated with human papillomavirus infection among women in the Northwest Territories. Can J Public Health 103(4):e282-e287

47. Bumbuliene Z, Alisauskas J (2012) Sexual behavior and high-risk human papillomavirus in 15- to 22-year-old Lithuanian women. Acta Obstet Gynecol Scand 91(4):511-513. doi:10.1111/j.16000412.2011.01334.x

48. Monsonego J, Zerat L, Syrjanen K, Zerat JC, Smith JS, Halfon P (2012) Prevalence of type-specific human papillomavirus infection among women in France: implications for screening, vaccination, and a future generation of multivalent HPV vaccines. Vaccine 30(35):5215-5221. doi:10.1016/j.vaccine.2012.06.013

49. Pista A, de Oliveira CF, Cunha MJ, Paixao MT, Real O (2012) Risk factors for human papillomavirus infection among women in Portugal: the CLEOPATRE Portugal Study. Int J Gynaecol Obstet: Off Organ Int Fed Gynaecol Obstet 118(2):112-116. doi:10.1016/j. ijgo.2012.03.028

50. Roset Bahmanyar E, Paavonen J, Naud P, Salmeron J, Chow SN, Apter D, Kitchener H, Castellsague X, Teixeira JC, Skinner SR, Jaisamrarn U, Limson GA, Garland SM, Szarewski A, Romanowski B, Aoki F, Schwarz TF, Poppe WA, De Carvalho NS, Harper DM, Bosch FX, Raillard A, Descamps D, Struyf F, Lehtinen M, Dubin G (2012) Prevalence and risk factors for cervical HPV infection and abnormalities in young adult women at enrolment in the multinational PATRICIA trial. Gynecol Oncol 127(3): 440-450. doi:10.1016/j.ygyno.2012.08.033

51. Roura E, Iftner T, Vidart JA, Kjaer SK, Bosch FX, Munoz N, Palacios S, Rodriguez MS, Morillo C, Serradell L, Torcel-Pagnon L, Cortes J, Castellsague X (2012) Predictors of human papillomavirus infection in women undergoing routine cervical cancer screening in Spain: the CLEOPATRE study. BMC Infect Dis 12:145. doi: $10.1186 / 1471-2334-12-145$

52. Yetimalar H, Kasap B, Cukurova K, Yildiz A, Keklik A, Soylu F (2012) Cofactors in human papillomavirus infection and cervical carcinogenesis. Arch Gynecol Obstet 285(3):805-810. doi:10.1007/ s00404-011-2034-3

53. Badano I, Pedrozo RW, Ruiz Diaz LS, Galuppo JA, Picconi MA, Campos RH, Liotta DJ (2011) Human papillomavirus (HPV) detection and Papanicolaou cytology in low-resource women in
Posadas city, Misiones, Argentina. Rev Argent Microbiol 43(4): 263-267. doi:10.1590/s0325-75412011000400005

54. Bell MC, Schmidt-Grimminger D, Jacobsen C, Chauhan SC, Maher DM, Buchwald DS (2011) Risk factors for HPV infection among American Indian and White women in the Northern Plains. Gynecol Oncol 121(3):532-536. doi:10.1016/j.ygyno.2011.02.032

55. Ferrera A, Tabora N, Flores Y, Zelaya A, Massuger L, Melchers WJ (2011) Assessment of HPV infection among female university students in Honduras via Roche linear array. Int $\mathrm{J}$ Gynaecol Obstet: Off Organ Int Fed Gynaecol Obstet 113(2):96-99. doi:10. 1016/j.ijgo.2010.11.016

56. Garland SM, Brotherton JM, Condon JR, McIntyre PB, Stevens MP, Smith DW, Tabrizi SN (2011) Human papillomavirus prevalence among indigenous and non-indigenous Australian women prior to a national HPV vaccination program. BMC Med 9:104. doi:10.1186/1741-7015-9-104

57. Kasap B, Yetimalar H, Keklik A, Yildiz A, Cukurova K, Soylu F (2011) Prevalence and risk factors for human papillomavirus DNA in cervical cytology. Eur J Obstet Gynecol Reprod Biol 159(1):168171. doi:10.1016/j.ejogrb.2011.06.021

58. Montalvo MT, Lobato I, Villanueva H, Borquez C, Navarrete D, Abarca J, Calaf GM (2011) Prevalence of human papillomavirus in university young women. Oncol Lett 2(4):701-706. doi:10.3892/ol. 2011.290

59. Shikova E, Todorova I, Ganchev G, Kouseva-Dragneva V, Kalascheva-Zaimova P (2011) Prevalence of human papillomavirus infection among female sex workers in Bulgaria. Int J STD AIDS 22(5):278-280. doi:10.1258/ijsa.2009.009362

60. Cercato MC, Mariani L, Vocaturo A, Carrone A, Terrenato I, Morano G, Benevolo M, Rollo F, Germelli C, Paolini F, Venuti A (2010) Predictors of human papilloma virus (HPV) infection in Italian women. J Med Virol 82(11):1921-1927. doi:10.1002/jmv. 21887

61. Iftner T, Eberle S, Iftner A, Holz B, Banik N, Quint W, Straube AN (2010) Prevalence of low-risk and high-risk types of human papillomavirus and other risk factors for HPV infection in Germany within different age groups in women up to 30 years of age: an epidemiological observational study. J Med Virol 82(11):19281939. doi:10.1002/jmv.21910

62. Ripabelli G, Grasso GM, Del Riccio I, Tamburro M, Sammarco ML (2010) Prevalence and genotype identification of human papillomavirus in women undergoing voluntary cervical cancer screening in Molise, central Italy. Cancer Epidemiol 34(2):162-167. doi:10. 1016/j.canep.2009.12.010

63. Chan PK, Ho WC, Wong MC, Chang AR, Chor JS, Yu MY (2009) Epidemiologic risk profile of infection with different groups of human papillomaviruses. J Med Virol 81(9):1635-1644. doi:10. 1002/jmv. 21575

64. Nielson CM, Harris RB, Flores R, Abrahamsen M, Papenfuss MR, Dunne EF, Markowitz LE, Giuliano AR (2009) Multiple-type human papillomavirus infection in male anogenital sites: prevalence and associated factors. Cancer Epidemiol Biomark Prev Publ Am Assoc Cancer Res Cosponsored Am Soc Prev Oncol 18(4):10771083. doi:10.1158/1055-9965.epi-08-0447

65. Silva KC, Rosa ML, Moyse N, Afonso LA, Oliveira LH, Cavalcanti SM (2009) Risk factors associated with human papillomavirus infection in two populations from Rio de Janeiro, Brazil. Mem Inst Oswaldo Cruz 104(6):885-891

66. Valles X, Murga GB, Hernandez G, Sabido M, Chuy A, Lloveras B, Alameda F, de San JS, Bosch FX, Pedroza I, Castellsague X, Casabona J (2009) High prevalence of human papillomavirus infection in the female population of Guatemala. Int J Cancer 125(5): 1161-1167. doi:10.1002/ijc.24444

67. Gonzalez C, Canals J, Ortiz M, Munoz L, Torres M, Garcia-Saiz A, Del Amo J (2008) Prevalence and determinants of high-risk human papillomavirus (HPV) infection and cervical cytological 
abnormalities in imprisoned women. Epidemiol Infect 136(2):215221. doi:10.1017/s0950268807008382

68. Lindau ST, Drum ML, Gaumer E, Surawska H, Jordan JA (2008) Prevalence of high-risk human papillomavirus among older women. Obstet Gynecol 112(5):979-989. doi:10.1097/AOG. 0b013e31818b0df2

69. Nielson CM, Harris RB, Dunne EF, Abrahamsen M, Papenfuss MR, Flores R, Markowitz LE, Giuliano AR (2007) Risk factors for anogenital human papillomavirus infection in men. J Infect Dis 196(8):1137-1145. doi:10.1086/521632

70. del Amo J, Gonzalez C, Losana J, Clavo P, Munoz L, Ballesteros J, Garcia-Saiz A, Belza MJ, Ortiz M, Menendez B, del Romero J, Bolumar F (2005) Influence of age and geographical origin in the prevalence of high risk human papillomavirus in migrant female sex workers in Spain. Sex Transm Infect 81(1):79-84. doi:10.1136/sti. 2003.008060

71. Beby-Defaux A, Bourgoin A, Ragot S, Battandier D, Lemasson JM, Renaud O, Bouguermouh S, Vienne Md Mde L, Agius G (2004) Human papillomavirus infection of the cervix uteri in women attending a Health Examination Center of the French social security. J Med Virol 73(2):262-268. doi:10.1002/jmv.20085

72. Shin HR, Franceschi S, Vaccarella S, Roh JW, Ju YH, Oh JK, Kong HJ, Rha SH, Jung SI, Kim JI, Jung KY, van Doorn LJ, Quint W (2004) Prevalence and determinants of genital infection with papillomavirus, in female and male university students in Busan, South Korea. J Infect Dis 190(3):468-476. doi:10.1086/421279

73. Chan PK, Chang AR, Cheung JL, Chan DP, Xu LY, Tang NL, Cheng AF (2002) Determinants of cervical human papillomavirus infection: differences between high- and low-oncogenic risk types. J Infect Dis 185(1):28-35. doi:10.1086/338010

74. Lazcano-Ponce E, Herrero R, Munoz N, Hernandez-Avila M, Salmeron J, Leyva A, Meijer CJ, Walboomers JM (2001) High prevalence of human papillomavirus infection in Mexican males: comparative study of penile-urethral swabs and urine samples. Sex Transm Dis 28(5):277-280

75. Nyari T, Cseh I, Woodward M, Szollosi J, Bak M, Deak J (2001) Screening for human papillomavirus infection in asymptomatic women in Hungary. Hum Reprod (Oxford, England) 16(10): 2235-2237

76. Sellors JW, Mahony JB, Kaczorowski J, Lytwyn A, Bangura H, Chong S, Lorincz A, Dalby DM, Janjusevic V, Keller JL (2000) Prevalence and predictors of human papillomavirus infection in women in Ontario, Canada. Survey of HPV in Ontario Women (SHOW) Group. CMAJ: Can Med Assoc J 163(5):503-508

77. Marrazzo JM, Koutsky LA, Stine KL, Kuypers JM, Grubert TA, Galloway DA, Kiviat NB, Handsfield HH (1998) Genital human papillomavirus infection in women who have sex with women. J Infect Dis 178(6):1604-1609

78. Burk RD, Ho GY, Beardsley L, Lempa M, Peters M, Bierman R (1996) Sexual behavior and partner characteristics are the predominant risk factors for genital human papillomavirus infection in young women. J Infect Dis 174(4):679-689

79. Davidson M, Schnitzer PG, Bulkow LR, Parkinson AJ, Schloss ML, Fitzgerald MA, Knight JA, Murphy CM, Kiviat NB, Toomey $\mathrm{KE}$ et al (1994) The prevalence of cervical infection with human papillomaviruses and cervical dysplasia in Alaska Native women. $\mathrm{J}$ Infect Dis 169(4):792-800

80. Palefsky JM, Shiboski S, Moss A (1994) Risk factors for anal human papillomavirus infection and anal cytologic abnormalities in HIV-positive and HIV-negative homosexual men. J Acquir Immune Defic Syndr 7(6):599-606

81. Bauer HM, Hildesheim A, Schiffman MH, Glass AG, Rush BB, Scott DR, Cadell DM, Kurman RJ, Manos MM (1993) Determinants of genital human papillomavirus infection in lowrisk women in Portland, Oregon. Sex Transm Dis 20(5):274-278
82. Ley C, Bauer HM, Reingold A, Schiffman MH, Chambers JC, Tashiro CJ, Manos MM (1991) Determinants of genital human papillomavirus infection in young women. J Natl Cancer Inst 83(14):997-1003

83. Rohan T, Mann V, McLaughlin J, Harnish DG, Yu H, Smith D, Davis R, Shier RM, Rawls W (1991) PCR-detected genital papillomavirus infection: prevalence and association with risk factors for cervical cancer. Int J Cancer 49(6):856-860

84. Feldman JG, Chirgwin K, Dehovitz JA, Minkoff H (1997) The association of smoking and risk of condyloma acuminatum in women. Obstet Gynecol 89(3):346-350. doi:10.1016/s00297844(97)00011-2

85. Simen-Kapeu A, La Ruche G, Kataja V, Yliskoski M, Bergeron C, Horo A, Syrjanen K, Saarikoski S, Lehtinen M, Dabis F, Sasco AJ (2009) Tobacco smoking and chewing as risk factors for multiple human papillomavirus infections and cervical squamous intraepithelial lesions in two countries (Cote d'Ivoire and Finland) with different tobacco exposure. Cancer Causes Control: CCC 20(2):163-170. doi:10.1007/ s10552-008-9230-X

86. Werden J, Schnatz PF, Mandavilli S, Allen G, Murphy JL, Greene JF, Egan JF, Sorosky JI (2008) Prevalence of the human papillomavirus in an inner-city indigent population with previously normal Pap tests. Journal Lower Genit Tract Dis 12(4):287-292. doi:10. 1097/LGT.0b013e31817e307b

87. Hajjaj AA, Senok AC, Al-Mahmeed AE, Issa AA, Arzese AR, Botta GA (2006) Human papillomavirus infection among women attending health facilities in the Kingdom of Bahrain. Saudi Med J 27(4):487-491

88. O'Keefe EJ, Gardner A, Currie MJ, Garland S, Tabrizi S, Bowden FJ (2006) Prevalence of genital human papillomavirus DNA in a sample of senior school-aged women in the Australian Capital Territory. Sex Health 3(2):91-94

89. de Sanjose S, Almirall R, Lloveras B, Font R, Diaz M, Munoz N, Catala I, Meijer CJ, Snijders PJ, Herrero R, Bosch FX (2003) Cervical human papillomavirus infection in the female population in Barcelona, Spain. Sex Transm Dis 30(10):788-793. doi:10.1097/ 01.olq.0000080177.82204.e0

90. Franceschi S, Castellsague X, Dal Maso L, Smith JS, Plummer M, Ngelangel C, Chichareon S, Eluf-Neto J, Shah KV, Snijders PJ, Meijer CJ, Bosch FX, Munoz N (2002) Prevalence and determinants of human papillomavirus genital infection in men. Br J Cancer 86(5):705-711. doi:10.1038/sj.bjc.6600194

91. Svare EI, Kjaer SK, Worm AM, Osterlind A, Meijer CJ, van den Brule AJ (2002) Risk factors for genital HPV DNA in men resemble those found in women: a study of male attendees at a Danish STD clinic. Sex Transm Infect 78(3):215-218

92. Muckerman DR (1994) Subclinical human papillomavirus infection in a high-risk population. J Am Osteopath Assoc 94(7):545-550, 555-547

93. Hildesheim A, Gravitt P, Schiffman MH, Kurman RJ, Barnes W, Jones S, Tchabo JG, Brinton LA, Copeland C, Epp J et al (1993) Determinants of genital human papillomavirus infection in lowincome women in Washington, D.C. Sex Transm Dis 20(5):279285

94. Wheeler CM, Parmenter CA, Hunt WC, Becker TM, Greer CE, Hildesheim A, Manos MM (1993) Determinants of genital human papillomavirus infection among cytologically normal women attending the University of New Mexico student health center. Sex Transm Dis 20(5):286-289

95. Kemp EA, Hakenewerth AM, Laurent SL, Gravitt PE, Stoerker J (1992) Human papillomavirus prevalence in pregnancy. Obstet Gynecol 79(5 ( Pt 1)):649-656

96. Meekin GE, Sparrow MJ, Fenwicke RJ, Tobias M (1992) Prevalence of genital human papillomavirus infection in Wellington women. Genitourin Med 68(4):228-232 
97. Melbye M, Palefsky J, Gonzales J, Ryder LP, Nielsen H, Bergmann O, Pindborg J, Biggar RJ (1990) Immune status as a determinant of human papillomavirus detection and its association with anal epithelial abnormalities. Int J Cancer 46(2):203-206

98. Moscicki AB, Palefsky J, Gonzales J, Schoolnik GK (1990) Human papillomavirus infection in sexually active adolescent females: prevalence and risk factors. Pediatr Res 28(5):507-513. doi:10. 1203/00006450-199011000-00018

99. Sherman JF, Mount SL, Evans MF, Skelly J, Simmons-Arnold L, Eltabbakh GH (2008) Smoking increases the risk of high-grade vaginal intraepithelial neoplasia in women with oncogenic human papillomavirus. Gynecol Oncol 110(3):396-401. doi:10.1016/j. ygyno.2008.05.015

100. Munk C, Svare EI, Poll P, Bock JE, Kjaer SK (1997) History of genital warts in 10,838 women 20 to 29 years of age from the general population. Risk factors and association with Papanicolaou smear history. Sexually transmitted diseases 24(10): $567-572$

101. Brisson J, Roy M, Fortier M, Bouchard C, Meisels A (1988) Condyloma and intraepithelial neoplasia of the uterine cervix: a case-control study. Am J Epidemiol 128(2):337-342

102. Hansen BT, Hagerup-Jenssen M, Kjaer SK, Munk C, Tryggvadottir L, Sparen P, Liaw KL, Nygard M (2010) Association between smoking and genital warts: longitudinal analysis. Sex Transm Infect 86(4):258-262. doi:10.1136/sti.2009.038273

103. Massad LS, Xie X, Darragh T, Minkoff H, Levine AM, Watts DH, Wright RL, D'Souza G, Colie C, Strickler HD (2011) Genital warts and vulvar intraepithelial neoplasia: natural history and effects of treatment and human immunodeficiency virus infection. Obstet Gynecol 118(4):831-839. doi:10.1097/AOG.0b013e31821a0f4d

104. Massad LS, Silverberg MJ, Springer G, Minkoff H, Hessol N, Palefsky JM, Strickler HD, Levine AM, Sacks HS, Moxley M, Heather Watts D (2004) Effect of antiretroviral therapy on the incidence of genital warts and vulvar neoplasia among women with the human immunodeficiency virus. Am J Obstet Gynecol 190(5): 1241-1248. doi:10.1016/j.ajog.2003.12.037

105. Luu HN, Amirian ES, Beasley RP, Piller L, Chan W, Scheurer ME (2012) Association between smoking and size of anal warts in HIV- infected women. Int J STD AIDS 23(11):792-798. doi:10.1258/ijsa. 2012.011420

106. Habel LA, Van Den Eeden SK, Sherman KJ, McKnight B, Stergachis A, Daling JR (1998) Risk factors for incident and recurrent condylomata acuminata among women. Popul-Based Stud Sex Transm Dis 25(6):285-292

107. Sopori M (2002) Effects of cigarette smoke on the immune system. Nat Rev Immunol 2(5):372-377. doi:10.1038/nri803

108. Peters EJ, Morice R, Benner SE, Lippman S, Lukeman J, Lee JS, Ro JY, Hong WK (1993) Squamous metaplasia of the bronchial mucosa and its relationship to smoking. Chest 103(5):1429-1432

109. Sekhon HS, Wright JL, Churg A (1994) Cigarette smoke causes rapid cell proliferation in small airways and associated pulmonary arteries. Am J Physiol 267(5 Pt 1):L557-L563

110. Feng Z, Hu W, Hu Y, Tang MS (2006) Acrolein is a major cigarette-related lung cancer agent: Preferential binding at p53 mutational hotspots and inhibition of DNA repair. Proc Natl Acad Sci U S A 103(42):15404-15409. doi:10.1073/ pnas.0607031103

111. Phillips DH, Hewer A, Scholefield JH, Skinner P (2004) Smokingrelated DNA adducts in anal epithelium. Mutat Res 560(2):167172. doi:10.1016/j.mrgentox.2004.02.014

112. Herrero R, Brinton LA, Reeves WC, Brenes MM, Tenorio F, de Britton RC, Gaitan E, Garcia M, Rawls WE (1989) Invasive cervical cancer and smoking in Latin America. J Natl Cancer Inst 81(3):205211

113. Wiley DJ, Elashoff D, Masongsong EV, Harper DM, Gylys KH, Silverberg MJ, Cook RL, Johnson-Hill LM (2009) Smoking enhances risk for new external genital warts in men. Int J Environ Res Public Health 6(3):1215-1234. doi:10.3390/ijerph6031215

114. Kjaer SK, Tran TN, Sparen P, Tryggvadottir L, Munk C, Dasbach E, Liaw KL, Nygard J, Nygard M (2007) The burden of genital warts: a study of nearly 70,000 women from the general female population in the 4 Nordic countries. J Infect Dis 196(10):1447-1454. doi:10. $1086 / 522863$

115. Daling JR, Sherman KJ, Weiss NS (1986) Risk factors for condyloma acuminatum in women. Sex Transm Dis 13(1):16-18 